The Journal of Animal \& Plant Sciences, 31(1): 2021, Page: 61-69

ISSN (print): 1018-7081; ISSN (online): 2309-8694

\title{
DEGRADATION PROCESS, PHYTOSOCIOLOGY AND RESTORATION OF GRASSES USED FOR GRAZING RUMINANTS IN BRAZIL
}

\author{
R. V. R. de Souza ${ }^{1}$, T. P. Dias-Silva ${ }^{*}$, A. L. da Silva ${ }^{1}$, M. J. de Araújo ${ }^{1}$, R. L. Edvan ${ }^{1}$ and L. R. Bezerra ${ }^{2}$ \\ ${ }^{1}$ Programa de Pós-Graduação em Zootecnia, Universidade Federal do Piauí, Campus Professora Cinobelina Elvas, \\ Rodovia Bom Jesus-Viana, BR 135, 64900000, Bom Jesus, Piauí, Brasil. \\ ${ }^{2}$ Universidade Federal de Campina Grande, Centro de Saúde e Tecnologia Rural, Av. Universitária, Bairro Cecília, \\ 58708110, Patos, Paraíba, Brasil. \\ ${ }^{*}$ Corresponding author’s email : tairon.mvet@gmail.com; ORCID ID: https://orcid.org/0000-0002-4786-1399
}

\begin{abstract}
The aim of this study is to present the main pasture grasses used in Brazil, the process of pasture degradation, pasture phytosociology, some undesirable pasture plants, and pasture restoration techniques. A wide plant availability and the high forage yield of its pastures make Brazil an important producer of plants for animal feed. The great majority of pastures in Brazil contain grasses of the genus Brachiaria, known for its strength and high forage potential. However, the pastures are undergoing constant degradation caused by improper handling, which leads to unsustainability. This is possibly due to extensive and extractive exploitation using a low level of technology and unsuitable management practices. Based on the principle that pastures can be restored, alternative techniques are required to promote improvements in forage quality. For this, it is important to recognize the undesirable pasture plants, which directly interfere with livestock production by competing with forage species for water, nutrients, space and light, as well as producing phytotoxins that prevent or suppress the growth of forage species. In the process of pasture restoration, the main objective is to maintain the vital functions of the ecosystem and to mitigate damage from undesirable plants through the immediate coverage of the soil.
\end{abstract}

Key words: management practices, pasture degradation, recovery, undesirable plants.

https://doi.org/10.36899/JAPS.2021.1.0193

Published online August 26, 2020

\section{INTRODUCTION}

Brazil has the potential to be a major producer of fodder plants for animal feed, as it is a country of excellent standing on the world stage, and has shown significant development in recent years (Souza et al., 2017). Grasses have always been regarded as low demand crops needing constant replanting, and these factors have resulted in low productivity rates and consequent economic failure. The wide availability in the country of plants with high forage yield is one of the factors that help increase the capacity of pastures, as shown in Table 1 (Emerenciano Neto et al., 2013; Fontes et al., 2014).

Table 1. Production of green biomass $\left(\mathrm{kg} \mathrm{ha}^{-1}\right.$ per cut) of tropical grasses.

\begin{tabular}{lccc}
\hline Scientific name & Genotype & $\begin{array}{c}\text { Production } \\
\left(\mathbf{k g ~ h a}^{-1} \mathbf{)}\right.\end{array}$ & Authors \\
\hline Brachiaria brizantha & Marandu & 7780 & Morais et al. (2014) \\
Brachiaria brizantha & MG4 & 8050 & Seidel et al. $(2014)$ \\
Brachiaria brizantha & Xaraés & 8432 & Alonso and Costa (2017) \\
Panicum maximum & Mombaça & 16063 & Lopes et al. (2016) \\
Brachiaria ruziziensis & Ruziziensis & 12050 & Rodrigues et al. (2014) \\
Andropogon gayanus & Andropogon & 4782 & \\
\hline
\end{tabular}

The great majority of the pastures found in Brazil are composed of grasses of the genus Brachiaria, due to its climatic tolerance and high forage potential. However, the tolerance of this species to tropical environments does not prevent the pastures being degraded by improper handling methods (Lisbôa et al.,
2016; Costa et al., 2017). The extent of Brachiaria pasture has been increasing in Brazil in comparison to other forages. It has become popular mainly because it is rustic and can adapt to the most varied edaphoclimatic conditions. Currently, Brazil exports seeds with a rate of approximately $80 \%$ germination for up to 40 countries, 
being the largest producer and exporter of tropical forage seeds in the world (Cardoso et al., 2014).

With the increase in the use of grasses from the Brachiaria and Panicum genera in Brazil but little technical knowledge about the optimum management methods for these pastures, there is a great need for research in this field. These species are the most used in animal production because they adapt well to tropical and subtropical climates and have high biomass production (Gomes et al., 2011; Portela et al., 2011).

In the 1990s the forages Brachiaria brizantha cv. Marandu and Andropogon gayanus cv. Planaltina were introduced to Brazil by Embrapa. Both were readily accepted by the farmers, especially the Marandu grass, due to its resistance to grasshoppers. After these forages, several cultivars of Panicum were introduced. In 2000, the Xaraés grass was brought in (Costa et al., 2008).

The genus Brachiaria belongs to the Poaceae family. It is native to Africa and widely used in tropical America. Although this type of forage establishes well, the development of a large number of undesirable plants can occur when it is not properly handled (Castro Junior et al., 2008). Marandu grass (Brachiaria brizantha) is an alternative for ruminants due to its agronomic characteristics, and has enabled large areas in Central Brazil to be used for pasture (Fontes et al., 2014).

MG4 grass (Brachiaria brizantha) is originally from Colombia and was introduced to Brazil by Matsuda Genética $\mathrm{n}^{\circ} 4$, in 1995, through the International Center for Tropical Agriculture (ICTA). It is a tolerant variety that can grow in regions with poor soils and low rainfall (due to its deep root system), revives well after burning and has good regrowth capacity (Fontes et al., 2014). The cultivar MG4 grows in clumps, with a height between 0 . 8 and $1.5 \mathrm{~m}$. It has small horizontal roots, hard and bends and covered with scales (Almeida et al., 2014).

Xaraés grass (Brachiaria brizantha) is a tropical grass native to Burundi, East Africa. This variety was introduced into Brazil in 1994 after various tests and in vitro culture. In the course of a decade it showed a good adaptation to regions with a very humid tropical climate and long periods of drought (4 to 5 months) and still remained green. This variety has high forage potential, rapid regrowth and very vigorous plants that reach $1.60 \mathrm{~m}$ (Almeida et al., 2014).

The Mombasa grass (Panicum maximum), is considered one of the most productive tropical forages available for animal feed (Simonetti et al., 2016). It is a grass with high yield and nutritional quality presenting many advantages for livestock production. Panicum maximum covers more than 20 million hectares in Brazil and, with the development of genetically improved cultivars, its high propagation capacity and ability to adapt to different types of soil and climate shows its importance as a tropical forage (Braz et al., 2017).

Andropogon grass a grass native to the African continent is perennial and 1.5 to $2.5 \mathrm{~m}$ height. It is well adapted to dry regions and sandy, acid soils with low fertility. When young it has good acceptability and nutritious qualities. However, it produces an inflorescence with hard stems and is poorly accepted by ruminants when in an advanced vegetative stage (Silva et al., 2014). According to Cavalcanti and colleagues (Cavalcanti et al., 2016), the Andropogon stands out for its high biomass production and tolerance to prolonged drought periods. With such characteristics, this grass is considered one of the species most adapted to certain Brazilian regions. It is currently widely used as cultivated pasture, mainly in the areas of the Cerrado biome.

Pasture degradation in Brazil

According to the Brazilian Association of Meat Export Industries (ABIEC, 2018), in 2015, the pasture area in Brazil corresponded to $167.487,880$ hectares. The Midwest represents $32 \%$, the North $25 \%$, the Northeast $21 \%$, the Southeast $14 \%$ and the South 9\% (Figure 1). These areas of cultivated pastures reflect, directly, the significant extent of herd grazing in Brazil. The extent is such that, of the 39.1 million animals slaughtered in the year 2015, only $13 \%$ come from animals finished in feedlot.

The data presented here could be considered to be even more significant because the livestock is grazing on degraded pastures. The unsustainable nature of this production system is evident, arguably enhanced by extensive and extractive exploitation at a low technological level with minimal use of proper management practices (Rocha Junior et al., 2013). For example, the Cerrado biome corresponds to approximately $24 \%$ of Brazilian territory, and more than half, approximately 32 million hectares, is in some stage of degradation The development of the herd kept on pasture can be maximized, not only with formation of new pasture areas, but also with restoration of degraded pastures, by using ecological principles and adopting appropriate management practices for each forage species.

Macedo (2005) defines pasture degradation as a gradual process of loss of vigor, productivity, natural restoration ability, the capacity to sustain production levels and the quality demanded by the animals, as well as to overcome the harmful effects of pests, diseases and undesirable plants, culminating in the advanced degradation of natural resources due to inadequate management (Figure 2). 


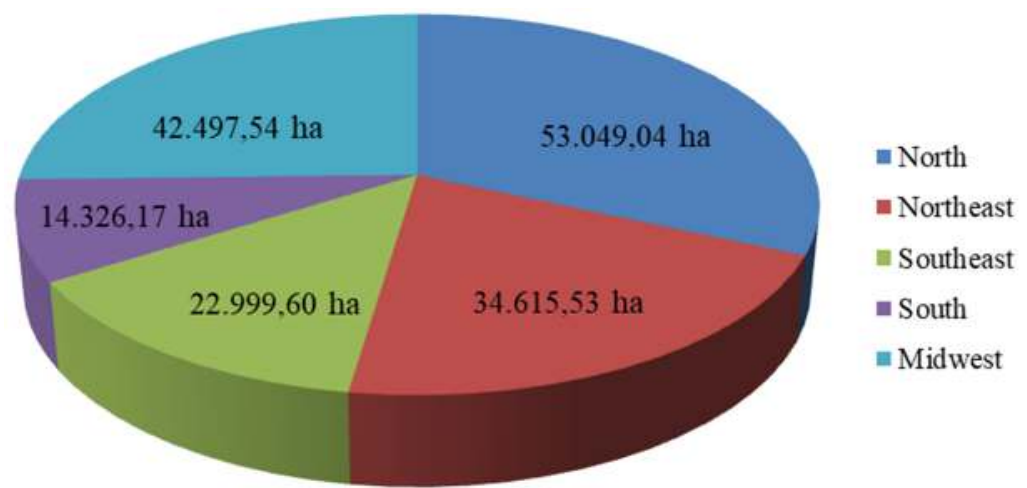

Figure 1. Pasture area (hectare, ha) in Brazil by region in 2015. Adapted from ABIEC (2018).

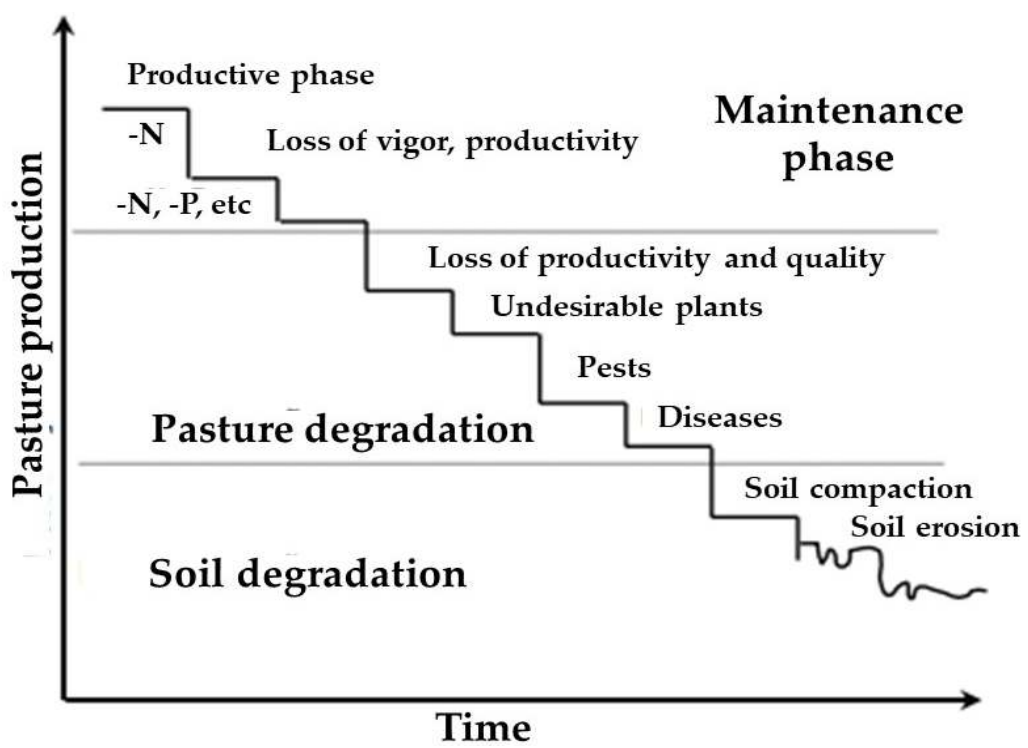

Figure 2. Graphical representation of the degradation process of cultivated pastures in different stages. Adapted from Macedo (2005).

The failure to manage pastures, combined with intense grazing, activates the degradation process. Consequently, attacks by pests and disease initiates soil degradation through the compaction and erosion (Figure 2).

Brazilian pastures are being cultivated for long periods without management practices, i.e., the natural resources of the soil are extracted for the cultivation of forage plants, so that, over the years, soil fertility decreases, triggering a number of problems in agricultural areas. Due to the fall in soil and plant productivity and reduction of animal support capacity by the area, the farmers abandon these sites for new agricultural fields (Pereira et al., 2013).

In the mid-1970s, the conventional African grasses that existed in Brazil began to be replaced by varieties with better adaptability and productivity. The Brachiaria, which also came from Africa, appeared as an option at that time. However, a short time later it was observed that it was very demanding with respect to soil fertility and consequently the pastures, under inappropriate management, began to degrade (Xavier et al., 2011).

According to Qi et al. (2012) and Gang et al. (2014), disordered overgrazing and deforestation are the major causes of desertification and pasture degradation, and thereby compromise ecosystem functions. In addition, pasture degradation is directly linked to climatic variations as well as human interference.

According to Balbino et al. (2011), the degradation of pasture has become one of the main signs of the low sustainability of livestock farming in several regions of Brazil. Factors such as high stocking rates, lack of replenishment of soil nutrients, and low technological investment have had negative consequences for the development and sustainability of livestock, resulting in low fodder supply, low zootechnical indexes and a low productivity of meat and milk per hectare. 
In this scenario (high levels of degraded pastures), farmers must seek alternatives to improve the forage conditions based on principles of pasture restoration. These methods aim to re-establish the forage production by keeping the same species or cultivar. The restoration process can be direct or indirect, depending on the degree of pasture degradation. In most cases it is necessary to prepare the soil and perform fertilization (Nogueira et al., 2015).

Phytosociology of pastures: The number of undesirable plants in the pasture depends on plant species, density, distribution, forage crop, spacing, soil, climate, management, and time of plantation. A form of floristic identification in agricultural areas is known as phytosociological survey. This provides temporal and spatial information on the plant community through frequency, density, abundance and relative importance indices of the plants in the ecosystem. Information on the number of individuals and the distribution of existing species in the pasture through a phytosociological study is of great relevance in the search for pasture management and restoration strategies (Firn, 2007; Santos et al., 2015). It is essential to know about the undesirable plant species in pastures, because each plant has particular properties and the effects of its infestation in cultivated areas may vary with the type of soil management. The objective of identification of undesirables is to know the individual effects and the interactions of plants that infest the diverse crops, in order to develop general and specific management regimes for undesirable species (Cruz et al., 2009).

Undesirable plants directly intervene in livestock production by competing with the forage species for water, nutrients, space and light, as well as producing phytotoxins that prevent or suppress the growth of forage species (Reigosa et al., 2013). The relevant characteristics of undesirable plants are those that influence the degree of interference with cultivated plants such as support capacity, arrangement and height of plants, climatic and environmental conditions, preferred soil type, and the period that these undesirable plants remain together with crops. However, the growth of plantations directly interferes with the determination of distance and plant installation the interposition rate of undesirable plants in crops, since the spacing between the plants determines the degree of competitiveness. The groups of weeds vary according to the size of the plant, and type of growth. For example, erect plant species produce little shade when compared to plants with prostrate habit (Batista et al., 2017).

Undesirable plants in pasture: In the pastures, a certain number of undesirable species spontaneously form a plant community, coexisting to a degree with the established forage plants. Some of these species can be considered innocuous, because they are accepted by ruminants and do not interfere with the established fodder plants. On the other hand, some species are undesirable because they compete with fodder plants or because they have toxic properties. It should be noted that not all plants demonstrated experimentally as undesirable should be considered to be toxic for animals because they do not produce clinic pathological conditions under natural conditions (Barbosa et al., 2005).

Undesirable plants are any species that germinate spontaneously and adversely affect the development of the crop, or opportunistic species occurring in degraded environments (Diniz et al., 2017). By competing for resources, undesirable plants promote low pasture support characteristics, increase pasture formation and restoration time, and poison or cause injury to the animals, compromising herd quality.

The identification of undesirable plants in pastures is important and the characteristics of these species should be understood before implementation of any program to restore degraded pastures. However, this can relatively easily be achieved through floristic surveys of undesirable plants and studies on phytosociology that can contribute information on the structure of the community in question. It is also important to carry out studies on floristic diversity to fine-tune recommendations for field management methods (Costa and Mesquita, 2016). A survey provides information on the composition (\%) of the undesirable plants present in the pastures (Table 2). Surveys by Silva et al. (2004) provided valuable information on the different plant species.

Table 2. Concentration of undesirable plants in pasture.

\begin{tabular}{llcc}
\hline Family & \multicolumn{1}{c}{ Scientific name } & Concentration (\%) & Authors \\
\hline Rubiaceae & Borreria verticillata (L.) G. F. W. Meyer & 6.69 & \\
Rubiaceae & Borreria latifolia (Aubl.) Schum & 3.12 & Silva et al. $(2004)$ \\
Oxilidaceae & Oxalis sp. & 1.62 & \\
Euphorbiaceae & Croton campestris St. Hil. & 21.31 & Galvão et al. \\
\hline Cyperaceae & Cyperus compressus L. & 0.60 & (2008) \\
Cyperaceae & Fimbristylis miliacea (L.) Vahl & 0.75 & 0.86 \\
Cyperaceae & Fimbristylis dichotoma (L). Vahl & & \\
\hline
\end{tabular}


Goulart et al. (2009) reported that undesirable plants remove the vital nutrients (e.g., nitrogen, phosphorus, and potassium) from the soil that otherwise could supply the nutritional requirements of pasture in the region. Thus, when these plants are allowed to develop along with the pasture there will be a loss of forage development. Little is known about the undesirable plants in Northeastern pastures, and there is, therefore, a need to obtain information to help develop effective ways of controlling these species. In addition, studies on the ecology of undesirable plants are crucial to inform control strategies. Pitelli (2014), points out that any program for the control of undesirable plants must consider the mode of reproduction and dispersion of the species. Without adequate knowledge of these undesirable plant traits, control attempts are usually uncoordinated and unsuccessful.

Pasture restoration: In the process of pasture restoration, use of right the type of grasses as well as the application of an appropriate management regime is critical if positive results are to be maintained. However, in the early stages of pasture restoration, the main objective is to make the vital functions of the ecosystem viable. However, it is often impossible to recreate the original structure of a system in one step. First, it is necessary to mitigate the effects of the undesirable elements through immediate coverage of the soil (Cann, 2000; Santos et al., 2015).

There are two types of degradation: agricultural and biological degradation. In agricultural degradation there is an increase in the proportion of undesirable plants in the pasture, gradually decreasing the support capacity of the pastures. In biological degradation, the soil loses the ability to sustain plant production adequately, leading to the replacement of pasture plants with plants adapted to low soil fertility or the appearance of bare areas where the vegetation has failed (Pitelli, 2014).

Degraded areas need to be restored because they are of fundamental importance in environmental, technical and economic terms. For the restoration of pastures, it is essential to institute the correct management of the forage plants as well increase the soil fertility. Given that the management of areas with some degree of degradation differs from that of areas that have been recently planted or managed intensively for a long time, it is extremely important to obtain accurate information on the use of nutrients by grasses. This information can help to reduce nutrient losses from the environment, thereby increasing production and profitability (Ieiri et al., 2010; Castagnara et al., 2011; Santini et al., 2015).

Effective pasture management aims to balance the quantity and quality of fodder to guarantee the nutritional requirements of the animals while ensuring the persistence and production of the grasses. Pasture productivity stems from the continuous emission of leaves and tillers, a process that ensures the restoration of the foliar area after animal grazing and creates perennial pasture (Costa et al., 2017). According to Pereira et al. (2013) management must be in balance with the environment in which it is being developed, maintaining soil fertility, microbiology, physical and chemical characteristics, and harmony with other wild species and local flora.

According to Ydoyaga et al. (2006) direct mechanical and chemical methods can also be used in the restoration of degraded pasture. The methods chosen must be appropriate to each specific production system and aim to maximize the relationship between environmental, social and economic elements. The mechanical methods refer to the sorting of soil that may be compacted due to the trampling of animals; the chemical methods involve fertilizing and correcting the soil by supplying it with nutrients necessary for plant vigor and development.

Other authors discuss direct and indirect techniques. In this paper, we present the results of a study of the genetic variability of the pasture and of the degradation of the pasture, with no permanent or temporary introduction of a new component to the system (Townsend et al., 2010). Indirect, when performed through mechanical, chemical and cultural practices, however, with crop - livestock integration, bieng annual pasture or an annual crop of grains for a certain period (Macedo, 2005). Both are used in Brazil (Table 3).

Table 3. Survey of degraded pasture recovery methods in Brazil.

\begin{tabular}{lccc}
\hline Method & Experimental Time & Region & Authors \\
\hline Direct & 6 months & Southeast & Santini et al. $(2015)$ \\
& 4.5 months & Southeast & Ieiri et al. $(2010)$ \\
& 2 months & Midwest & Castro Junior et al. $(2008)$ \\
\hline Indirect & 4.6 months & Northeast & Ydoyaga et al. $(2006)$ \\
& 3.8 months & Northeast & Silva et al. $(2004)$ \\
& 43 months & North & Costa et al. $(2004)$ \\
\hline
\end{tabular}


Santini et al. (2015) working with direct methods, observed that the use of liming and fertilization, in a single application, is not sufficient for the complete recovery and increase of the productivity and quality of B. decumbens Stapf. cv. Basilisk. However, in order to evaluate the different doses and mode of application of phosphorus during the recovery process of a degraded pasture of the same grass, Ieiri et al (2010) verified that the application of $0,50,100$, and $150 \mathrm{~kg}$ of $\mathrm{P}_{2} \mathrm{O}_{5} \mathrm{ha}^{-1}$ promoted responses in dry matter productivity of 1607.6, $2146.7,2599.4$, and $2594.0 \mathrm{~kg} \mathrm{ha}^{-1}$, respectively, whereas the methods of phosphorus application did not influence productivity.

Ydoyaga et al. (2006) working with $B$. decumbens Stapf using direct and indirect methods verified that the deferment of pasture for 138 days in the rainy period assists its recovery, especially when associated with nitrogen and phosphate fertilization. Silva et al. (2004) observed that a system without soil preparation, associated with phosphate fertilization, was the most efficient for the recovery of B. humidicola pasture, and that the pasture presented satisfactory recovery results with 113 days postponement. Costa et al. (2004) obtained satisfactory results by using various techniques - harrowing, plowing + harrowing, with or without legumes, associated with phosphate fertilization - for the recovery of degraded pastures of $B$. brizantha cv. Marandu.

Recovery by direct methods (plowing and harvesting) is not efficient, and causes a possible reduction in the grass population (Carvalho et al., 2017). Townsend et al. (2010) observed in direct recovery / renovation, costs went from $\mathrm{R} \$ 800.00$ for low intervention to $1.950,00 \mathrm{ha}^{-1}$ for high, values that can prevent the adoption of medium and high-level intervention technologies.

Barducci et al. (2009), using indirect methods, found that the simultaneous cultivation of corn with $P$. maximum cv. Mombasa compromises grain yield, and corn intercropping with $B$. brizantha cv. Marandu presents higher dry mass yield. Araújo et al. (2018) found that in formation or renewal of pasture through croplivestock integration (B. brizantha cv. Marandu + maize), the exclusive operational cost (COE) of the pasture was $\mathrm{R} \$ 1.123,80 \mathrm{ha}^{-1}$, which is independent of $\left(\mathrm{R} \$ 561,40 \mathrm{ha}^{-}\right.$ $\left.{ }^{1}\right)$. With this approach, the average gross revenue (R\$ $\left.1.329,00 \mathrm{ha}^{-1}\right)$, less the corn COE (R $\left.\$ 561.40 \mathrm{ha}^{-1}\right)$, gave a positive gross margin $\left(\mathrm{R} \$ 767.60 \mathrm{ha}^{-1}\right)$.

Direct or indirect recovery methods require rigorous cost analysis as they demand high investment. Both methods can be used, the degree of degradation determines the investment required. In advanced cases of degradation, indirect methods prove more efficient.

Final considerations: The degradation process is caused by exploitative and extractive practices. To obtain positive results in the process of grass restoration, it is essential to know the phytosociological aspects of the pasture and to identify undesirable plants and understand their mode of establishment in the area. These plants directly interfere with livestock production by competing with forage species. In the process of pasture restoration, the implementation of appropriate management practices is essential. These practices should consider the level of degradation, and seek to achieve soil-plant balance in order to guarantee the nutritional requirements for the animals, and at the same time ensure the persistence and production of grasses.

Author Contributions: LRB, MJA, RLE and TPDS conceived and designed the study. TPDS, RVRS and ALS contributed to the writing of the manuscript.

Conflicts of Interest: The authors declare no conflict of interest.

\section{REFERENCES}

ABIEC - Brazilian Association of Meat Exporting Industries. Livestock Profile in Brazill. São Paulo. 2018.

Almeida, D.J., I. F. Silva, F. P. M. Silveira, R. D. Santiago and J. R. C. Costa. (2014). Cespitosa and decumbent poaceae fertilized with NPK: effects on soil aggregation. Pesqui. Agropecu. Trop., 44(1):50-55.

Alonso, R. A. and L. V. C. Costa. (2017). Agronomic characters of $\mathrm{b}$. brizantha $\mathrm{cv}$. xaraés $(\mathrm{mg} 5)$, under different doses of dairy cattle manure biofertilizer. Rev. Bras. Eng. Biossistemas, 11(4):400-411.

Araújo, M. A., M. A. Lopes and M. G. Cardoso. (2018). Economic viability of corn (Zea mays) for grains under no-tillage in the integrated production system in pasture recovery. Nucleus Animalium, 10(1):19-34.

Balbino, L. C., L .A. M. Cordeiro, V., Porfírio-Da-Silva, A. Moraes, G. B. Martínez, R.C. Alvarenga, N.A. Kichel, R. S. Fontaneli, H. P. Santos, J. C. Franchini and P. R. Galerani. (2011). Technological developments and productive arrangements for forestry livestock integration systems in Brazil. Pesq. Agropec. Bras., 46(10):1-12. $\quad$ DOI: $\quad 10.1590 / \mathrm{S} 0100$ 204X2011001000001

Barbosa, J. D., C. M. C. Oliveira, M. D. Duarte, P. V. Peixoto and C. H. Tokarnia. (2005). Experimental and natural poisoning by Experimental and natural poisoning by Ipomoea asarifolia (Convolvulaceae) in buffaloes and other ruminants. Pesqui. Vet. Bra., 25(4):231234. DOI: $10.1590 / \mathrm{S} 0100-736 X 2005000400008$ 
Barducci, R. S. A., C. Costa, C. A. C. Crusciol, É. Borghi, , T. C. Putarov and L. M. N. Sarti. (2009). Production of Brachiaria brizantha and Panicum maximum with corn and nitrogen fertilization. Arch. Zootec., 58(222):211-222.

Batista, P. S. C., V. S. Oliveira, V. B. Souza, A. J. Carvalho and I. Aspiazú. (2017). Phytosociological survey of weeds in erect prostrate cowpea cultivars. Planta Daninha, 35:1-9. DOI: 10.1590/s010083582017350100031

Braz, T. G. S., J. A. Martuscello, L. Jank, D. M. Fonseca, M.D.V. Resende and A. B. Evaristo. (2017). Genotypic value in hybrid progenies of Panicum maximum Jacq. Cienc. Rural, 47(9):1678-4596. DOI: $10.1590 / 0103-8478$ cr20160599

Cann, M. A. (2000). Clay spreading on water repellent sands in the south east of South Australiapromoting sustainable agriculture. J. Hydrol., 4:231-232.

Cardoso, E. D., M. E. Sá, K. I. Haga, F. F. S. Binotti, D. C. Nogueira and W. V. Valério Filho. (2014). Physiological performance and overcoming dormancy in Brachiaria brizantha seeds submitted to chemical treatment and artificial aging. Semina: Ciênc. Agrár., 35(1):21-38, DOI: 10.5433/1679-0359.2014v35n1p21

Carvalho, W. T. V., D. C. Minighin, L. C. Gonçalves, D.F.Q. Villanova, R. M. Mauricio and R. V. G. Pereira. (2017). Degraded pastures and recovery techniques: Review. Pubvet, 11(10):1036-1045, DOI: 10.22256/PUBVET.V11N10.1036-1045.

Castagnara, D. D., E. E. Mesquita, M. A. Neres, P. S. R. Oliveira, B. B. Deminicis and R. Bamberg. (2011). Nutritional value and structural characteristics of tropical grasses under nitrogen fertilization. Arch. Zootec., 60(232):931-942, DOI: $10.4321 /$ S0004-05922011000400010

Castro Junior, T. G., A. C. Fernandes and P. Rossi Junior. (2008). Herbicides in the management of invaders in pasture of Brachiaria brizantha cv. Marandu, in Mato Grosso, Brazil. Rev. Acad.: Ciênc. Agrári. Ambient., 6(1):109-118.

Cavalcanti, A. C., E. O. S. Saliba, L. C. Gonçalves, N. M. Rodriguez, I. Borges and A. L. C. C. Borges. (2016). Consumption and apparent digestibility of Andropogon gayanus hay harvested at three different ages. Ciênc. Anim. Bras., 17(4):482490, DOI: 10.1590/1089-6891v17i416026

Costa, C., P. R. L. Meirelles, J. J. Silva and M. A. Factori (2008). Evolution of cultivated pastures and cattle numbers in Brazil. Vet. e Zootec., 15(1):817.

Costa, J. P. and M. L. R. Mesquita. (2016). Floristic and phytosociology of weeds in pastures in
Maranhão State, Northeast Brazil. Rev. Cienc. Agron., 47(2):414-420.

Costa, N. L., L. Jank, J. A. Magalhães, A. N. A. Rodrigues, F. H. S. Fogaça, A. B. Bendahan and F. J. S. Santos. (2017). Forage productivity, chemical composition and morphogenesis of Megathyrsus maximus cv. Mombasa under rest periods. Pubvet, 11(11):1169-1174, 10.22256/pubvet.v11n11.1169-1174

Cruz, D. L. S., G. S. Rodrigues, F. O. Dias, J. M. A. Alves and J. A. A. Albuquerque. (2009). Weed survey in an area rotated with soybean, corn and irrigated rice crops in the Cerrado of Roraima. Rev. Agro@mbiente, 3(1):58-63, DOI: 10.18227/1982-8470ragro.v3i1.248

Diniz, K. D., N. C. Macedo, G. F. Portela, and L. P. Rezende. (2017). Weed seed bank in pasture area Panicum maximum Jacq. Cultivating Mombasa in the municipality of Balsas - MA. Biodiversid.. 16(3):1-28.

Emerenciano Neto, J. V., G. S. Difante, D. B. Montagner, M. G. S. Bezerra, R. C. P. Galvão, and R. I. G. Vasconcelos. (2013). Structural characteristics of the canopy and forage accumulation in tropical grasses, under intermittent stocking and grazed by sheep. Biosci. J., 29(4):962-973.

Firn, J. (2007). Developing strategies and methods for rehabilitating degraded pastures using native grasses. Ecol. Manag. Restor., 8:183-187.

Fontes, J. G. G., J. L. Fagundes, A. A. Backes, L. T. Barbosa, E. S. A. Cerqueira, Silva, L. M. and M. A. S. Juciléia. (2014). Dry mass accumulation in cultivars of Brachiaria brizantha submitted to defoliation intensities. Semina: Ciênc. Agrár., 35(3):1425-1438. DOI: $10.5433 / 1679$ $0359.2014 \mathrm{v} 35 \mathrm{n} 3 \mathrm{p} 1425$

Galvão, S. R. S., I. H. Salcedo and F. F. Oliveira. (2008). Accumulation of nutrients in sandy soils fertilized with cattle manure. Pesq. Agropec. Bras.a, 43(1):99-105.

Gang, C., W. Zhou, Y. Chen, Z. Wang, Z. Sun, J. Li and I. Odeh. (2014). Quantitative assessment of the contributions of climate change and human activities on global grassland degradation. Environ. Earth Sci., 72(1):4273-4282. DOI: 10.1007/s12665-014-3322-6

Gomes, R. A., B. Lempp, L. Jank, G. C. Carpejani and M. G. Morais. (2011). Anatomical and morphophysiological characteristics of leaf blades from Panicum maximum genotypes. Pesq. Agropec. Bras. 46(2):205-211, DOI: 10.1590/S0100-204X2011000200013

Goulart, I. C. G. R., A. Merotto Junior, N. B. Perez and A. Kalsing. (2009). Control of Annoni-2 grass (Eragrostis plano) with pre-emergent herbicides in association with different management 
methods of the native field. Planta daninha, 27(1):181-190. DOI: $\quad 10.1590 /$ S010083582009000100023

Ieiri, A. Y., R. M. Q. Lana, G. H. Korndörfer and H. S. Pereira. (2010). Sources, doses and modes of application of phosphorus in pasture recovery with Brachiaria. Cienc. e Agrotecnologia, 34:1154-1160. DOI: $\quad 10.1590 /$ S141370542010000500011

Lisbôa, F. M., G. K. Donagemma, D. L. Burak, R. R. Passos and E. S. Mendonça (2016). Latossolo quality indicators related to the degradation of pastures. Pesq. Agropec. Bras., 51(9):11841193. DOI: $10.1590 / \mathrm{s} 0100-204 \times 2016000900018$

Lopes, A. S., F. E. Torres, E. D. Fanaya Júnior, A. A. Silva Neto, A. R. A. Margatto and M. J. Kraeski. (2016). Productivity of forage grasses at different times under irrigation. Rev. Ciênc. Agrár., 59(2):173-180.

Macedo, M. C. M. (2005). Pasture degradation: concepts, alternatives and recovery methods. Informe Agropec., 26:36-42.

Morais, J. A. S., M. F. S. Queiroz, A. Keli, A. Veja, G. Fiorentini, R. C. Canesin, R. A. Reis and T. T. Berchielli. (2014). Effect of supplementation frequency on intake, behaviorand performance in beef steers grazing Marandu grass. Anim. Feed Sci. Technol., 189:63-71.

Nogueira, A. K. S., R. A. R. Rodrigues, B. S. Castro, T. F. Nogueira, J. J. N. Silva, M. Behling, M. Mombach, N. Armacolo and J. G. Silveira. (2015). Emissions of nitrous oxide and methane from the soil in pasture recovery areas in Matogrossense Amazon. Quim. Nova, 38(7):937-943, DOI: 10.5935/0100-4042. 20150109

Pereira, D. N., T. C. Oliveira, T. E. Brito, J. A. F. Agostini, P. F. Lima, A. V. Silva, C. S. Santos and M. Bregagnoli. (2013). Diagnosis and recovery of degraded pasture areas. Rev. Agrogeoambiental, 1:49-53, DOI: 10.18406/ 2316-1817v1n12013578

Pitelli, R.A. (2014). Genetically modified plants and environmental safety: a critical analysis. Planta daninha, 32(1):235-241.

Portela, J. N., C. G. S. Pedreira, C. G. Silveira and G. J. Braga. (2011). Demography and tiller density of brachiaria grass under grazing in intermittent stocking. Pesq. Agropec. Bras. 46(3):315-322, DOI: $10.1590 / \mathrm{S} 0100-204 X 2011000300013$

Qi, J., J., Chen, S. Wan and L. Ai. (2012). nderstanding the coupled natural and human systems in Dryland East Asia. Environmental Res. Lett.. 7(1):015202, DOI: $\quad 10.1088 / 1748-9326 /$ $7 / 1 / 015202$
Reigosa, M., A. S. Gomes, A. G. Ferreira and F. Borghetti. (2013). Allelopathic research in Brazil. Acta Bot. Bras., 27(4):629-646, DOI: 10.1590/S0102-33062013000400001

Rocha Junior, P. R., V. M. Silva and G. P. Guimarães. (2013). Degradation of Brazilian pastures and recovery practices. Enciclopédia Biosfera, 9(17):952-968.

Rodrigues, R. C., T. V. R. Sousa, M. A. A. Melo, J. S. Araújo, R. P. Lana, C. S. Costa, M. E. Oliveira, M. O. M. Parente and I. B. M. Sampaio. (2014). Agronomic, morphogenic and structural characteristics of tropical forage grasses in northeast Brazil. Trop. grassl.-Forrajes trop., 2:214-222.

Santini, J. M. K., S. Buzetti, F. S. Galindo, E. Dupas and D. N. Coaguila (2015). Management techniques for the recovery of degraded pastures of brachiaria grass (Brachiaria decumbens Stapf cv. Basilisk). B. Ind. Anim. 72(4):331-340.

Santos, M. V., E. A. Ferreira, D. M. Fonseca, L. R. Ferreira, L. D. T. Santos and D. V. Silva. (2015). phytosociological and forage production in molasses grass pasture. Rev. Ceres, 62(6):561-567. DOI: 10.1590/0034737X201562060008

Seidel, E. P., I. F. S. Gerhardt, D. D. Castagnara and M. A. Neres. (2014). Effect of season and sowing system of Brachiaria brizantha in intercropping with corn, on production components and physical properties of the soil. Ciênc. Agrár., 35(1):55-66

Silva, D. C., A. A. Alves, M. S. B. Lacerda, M. A. Moreira Filho and M. E. Oliveira. (2014). Nutritional value of andropogon grass in four regrowth ages in the rainy season. Rev. Bras. Saúde Prod. Anim. 15(3):626-636. DOI: 10.1590/S1519-99402014000300004

Silva, M. C., M. V. F. Santos, J. C. B. Dubeux Júnior, M. A. Lira, W. S. Melo, T. N. Oliveira and G. G. L. Araújo. (2004). Evaluation of Methods for Recovering Brachiaria Pastures in Agreste de Pernambuco. 2. Nutritional Value of Forage. R. Bras. Zootec., 33(6):2007-2016.

Silva, M. C., M. V. F. Santos, J. C. B. Dubeux Júnior, M. A. Lira, D. F. Y. Santana, I. Farias and V. F. Santos. (2004). Evaluation of Methods for Recovering Brachiaria Pastures in Agreste de Pernambuco. 1. Quantitative aspects. R. Bras. Zootec., 33(6):1999-2006.

Simonetti, A., W. M. Marques and L. V. C. Costa. (2016). Yield of mombaça grass (Panicum maximum), with different doses of biofertilizer. Rev. Bras. Eng. Biossistemas, 10(1):107-115.

Souza, J. R., J. J. Lacerda, O. M. Morais and J. P. Silva. (2017). Germinative potential of encrusted seed of 
tropical forage species. Cienc. Rural, 47(2):1-6. DOI: $10.1590 / 0103-8478 \mathrm{cr} 20151089$

Townsend, C. R., N. L. Costa and A. G. A. Pereira. (2010). Economic aspects of pasture recovery in the Brazilian Amazon. Amazônia: Ciênc. Desenvol. 5:27-49.

Xavier, D. F., F. J. S. Lédo, D. S. C. Paciullo, M. F. A. Pires and R. M. Boddey. (2011). Burlap dynamics in brachiaria pastures in silvopastoral and monoculture systems. Pesqui. Agropecu. Bras., 46(10):1214-1219. DOI: $\quad 10.1590 / \mathrm{S} 0100$ 204X2011001000014

Ydoyaga, D. F., M. A. Lira, M. V. F. Santos, J. C. B. Dubeux Júnior, M. C. Silva, V. F. Santos and A. P. M. Fernandes (2006). Pasture recovery methods of Brachiaria decumbens Stapf. in Agreste Pernambucano. Rev. Bras. Zootec., 35(3):699-705. DOI: $\quad 10.1590 / \mathrm{S} 1516-35982006000300010$. 